\title{
ПСИХОЛОГІЧНІ ОСОБЛИВОСТІ СИНДРОМУ ЕМОЦІЙНОГО ВИГОРАННЯ У МЕНЕДЖЕРІВ КОМЕРЦІЙНИХ ОРГАНІЗАЦІЙ
}

\author{
Ольга Сидоренко \\ кандидат психологічних наук, доцент, доцент кафедри \\ загальної і соціальної психології та психотерапії \\ Національний педагогічний університет імені М. П. Драгоманова \\ 01601, Україна, м. Київ, вул. Пирогова, 9 \\ OlgaBorisoUA@gmail.com, https://orcid.org/0000-0003-0925-4966
}

\section{Ельга Яновська}

магістрантка спеціальності «Психологія» факультету психології

Національний педагогічний університет імені М. П. Драгоманова

01601, Україна, м. Київ, вул. Пирогова, 9

hemmmy20@gmail.com, https://orcid.org/0000-0002-8676-9544

\begin{abstract}
Анотація
У статті здійснено теоретичний аналіз наукових підходів до трактування поняття «емоційне вигорання», висвітлено його симптоми. Емоційне вигорання представляє собою стан емоційного, психічного, фізичного виснаження, що розвивається як результат хронічного стресу, викликаного власною роботою, i поєднує в собі емоційну спустошеність, деперсоналізацію і редукцію особистісних досягнень. Розкрито причини та особливості прояву емоційного вигорання. Виділено основні групи факторів, які зумовлюють виникнення синдрому емоційного вигорання: особистісний, рольовий, організаційний. Виявлено фази формування синдрому емоційного вигорання у менеджерів комерційних організацій: фаза напруження, фаза резистенції, фаза виснаження. Домінуючими симптомами вигорання у фазі напруження є: незадоволення собою, своєю професією, посадою, конкретними обов'язками; у фазі резистенції - симптом неадекватного вибіркового емоційного реагування та симптом редукції професійних обов'язків; у фазі виснаження - симптоми емоційного дефіциту, емоційної відчуженості та деперсоналізації.

В дослідженні визначено, що менеджери комерційних організацій застосовують переважно механізми психологічного захисту як раціоналізація та проекція. Виявляють схильність до приписування власних негативних почуттів, переживань, намірів, бажань іншим людям. Шукають переконливі докази, виправдування для пояснення своїх дій і бажань, які є недостатньо схвалюваними. Це спроби досліджуваних довести, що їх поведінка $є$ раціональною і виправданою, а тому соціально схваленою, вона допомагає розв'язувати конфліктні ситуації або долати труднощі на шляху до досягнення мети, уникаючи надмірні емоційні хвилювання. Майже половина респондентів із загальної вибірки досліджуваних мають середній рівень тривожності та невротизації. Відчувають постійно зниження настрою, хвилювання, занепокоєння, швидку стомлюваність, слабкість, незадоволення своїх потреб і бажань, невизначеність у майбутньому.
\end{abstract}


Встановлено статистично значущий позитивний взаємозв'язок між проявами синдрому емоційного вигорання та рівнем тривожності й невротизації у менеджерів комерційних організацій. Зазначено, що для запобігання синдрому емоційного вигорання у менеджерів комерційних організацій буде сприяти розробка відповідної психокорекційної програми.

Ключові слова: емоційне вигорання, тривожність, невротизація, стрес, менеджери комерційних організацій, професійна деформація.

\section{Вступ}

В сучасних умовах ринкової економіки, посилення конкуренції на національному та міжнародному рівні, відбувається зростання вимог до особистості професіонала. Це стосується менеджерів, що здійснюють свою діяльність в умовах комерційних організацій.

Діяльність сучасного менеджера характеризується високою емоційною насиченістю і когнітивною складністю, необхідністю швидкого реагування на зміни, що відбуваються на ринку товарів і послуг, прийняття відповідних рішень у ситуаціях, пов'язаних з невизначеністю та ризиком, що вимагає високої комунікативної компетенції і мобільності та, як наслідок, психічної й фізичної витривалості. Тобто, їх діяльність відбувається умовах постійної нервово-психічної напруженості, стресу та потребує максимальної мобілізації енергетичних ресурсів і захисних сил організму.

Одним 3 негативних наслідків зіткнення особистості зі складними умовами сучасного життя $є$ виникнення емоційного вигорання - дезадаптаційного феномену, що характеризується втратою індивідом творчого настрою стосовно своєї діяльності, дестабілізацією міжособистісних стосунків у системі «людина-людина», агресивними проявами (дратівливість, тривожність, занепокоєння, схвильованість, гнів), психосоматичними розладами.

Проблема вигорання вивчалась достатньо великою кількістю зарубіжних та вітчизняних вчених, таких, як: В. Бойко (Бойко, 2003), Н. Водоп'янова (Водоп'янова, 2008), М. Грабе (Грабе, 2008), Е. Зеєр (Зеер, 2005), Л. Карамушка, Т. Зайчикова (Карамушка \& Зайчикова, 2006), Р. Кочюнас (Кочюнас, 1990), C. Maslach (Maslach, 2001), S. Hobfoll (Hobfoll, 2001), M. Jurado (Jurado, 2019), S. Mérida-López (Mérida-López, 2017), M. Ventura (Ventura, 2015).

Синдром емоційного вигорання $є$ станом емоційного, психічного, фізичного виснаження, що розвивається як результат хронічного стресу, пов'язаного з роботою і колективом. Він виникає через довготривале емоційне напруження, в результаті внутрішнього накопичення негативних емоцій, переживань і стресів, які не знаходять свого вивільнення. Емоційне вигорання призводить до розвитку негативної самооцінки, негативного ставлення до роботи, втрати здатності співчувати іншим людям, і як наслідок до загального виснаження організму та психіки, появі відчуття власної даремності, виникнення психосоматичних захворювань (Бойко, 2003; Карамушка, 2006; Кочюнас, 1990; Маслач, 2001; Hobfoll, Canetti-Nisim \& Johnson, 2006; Jurado \& Pérez-Fuentes, 2019).

В. Бойко розглядає явище вигорання як вироблений особистістю механізм психологічного захисту у формі повного або часткового виключення емоцій у відповідь на психотравмуючі впливи (Бойко, 2003).

Синдром професійного вигорання є професійною деструкцією особистості, яка представлена у вигляді стійких психічних переживань, які суб'єктивно сприймаються 
працівниками як стресові та мають дезадаптивний характер (Водоп'янова, 2008). Прояви цього синдрому пов'язані з високим рівнем тривожності особистості, якій проявляється в емоційній нестабільності, неврівноваженості, боязкості, невпевненості у собі та надмірної напруженості (Грабе, 2008).

Емоційне вигорання $є$ динамічним процесом і складається 3 трьох фаз: фаза тривоги, яка виникає при першій появі стресора (організм включає механізми саморегуляції захисних процесів); фаза «резистентності» (опору) настає в результаті тривалої дії стресора (організм намагається збалансувати витрати адаптаційних резервів); фаза виснаження, якщо дія стресу продовжується і людина неспроможна адаптуватися, відбувається втрата цінних ресурсів особистості, або їх стає недостатньо, щоб відповідати вимогам соціуму (Сельє, 1982; Бойко, 2003; Hobfoll, 2001).

До основних груп факторів, що сприяють формуванню синдрому емоційного вигорання відносяться: 1) особистісний (емоційна ригідність, низький рівень самоповаги, занадто висока або низька мотивація до успіху, високий рівень емпатії, реакція не стресові ситуації, вік, стаж роботи); 2) рольовий (рольова невизначеність, незадоволення професійним та особистісним зростанням, низький соціальний статус); 3) організаційний (нестабільність заробітної платні, ненормований графік роботи, конфлікти з керівництвом та колегами).

Симптомами емоційного вигорання є: 1) емоційне виснаження, виражається через невдоволення власною роботою та емоційній спустошеності; 2) деперсоналізація/ дегуманізація, негативне, цинічне ставлення до оточуючих, деформація стосунків 3 колегами, поява почуття провини, людина обирає автоматичне «функціонування» i всіляко уникає навантажень; 3) редукція особистих досягнень, виражається у почуттях власної некомпетентності, в негативній оцінки себе, своїх досягнень та успіхів, заниженні своїх службових переваг, своїх можливостей, і як наслідок відчуття незадоволеності та низька самооцінка (Орел, 2001; Maslach \& Schaufeli \& Leiter, 2001).

Розвиток цього синдрому призводить до втрати важливих компонентів в структурі професійно-особистісних компетенцій до фінальної депресивної невротизації особистості (Величковская, 2005; Никифоров, 2002). Чим більше людина впевнена у своїй компетентності, здатна ефективно виконувати конкретні дії у певній галузі, справлятися 3 несприятливими життєвими ситуаціями і долати їх, тим менше вона вигорає на своєму робочому місці (Ventura, Salanova \& Llorens, 2015; Jurado, Pérez-Fuentes, Linares, Márquez \& Martínez, 2018).

На думку Н. Водоп’нової, К. Старченкової, стресогенність роботи саме менеджерів зумовлюється специфічними організаційними факторами: автономністю та відповідальністю при проведенні торгівельних переговорів (кількість та обсяг укладених договорів); особливістю трудових взаємовідносин (висока мобільність, постійна зміна i розширення кола спілкування за рахунок нових клієнтів); високими вимогами до емоційно-вольових якостей (висока персональна відповідальність щодо зобов'язань перед клієнтами та моральна за імідж компанії роботодавця).

Розвитку емоційного вигорання у менеджерів комерційних організацій сприяють i особистісні фактори (психологічні особливості людини), такі як: низька комунікабельність, емоційна неврівноваженість, низький рівень соціальної сміливості та 
експресивності, недовірливість, зосередженість на собі, низька мотивація досягнень, нонконформізм, низька самооцінка (Водопьянова \& Старченкова, 2008).

А. Леонтьєва виділяє такі особливості прояву професійно-емоційного вигорання, як реакції на хронічні та робочі стресори:

- для менеджерів вищої ланки, які мають найбільшу владу і несуть відповідальність за діяльність усієї компанії характерні ознаки психофізіологічного виснаження, тривоги, депресії, використання неадекватних моделей поведінки.

- для лінійних менеджерів, які відповідальні за стан і розвиток організації або іiі підрозділів (директори, бригадири) характерні підвищена когнітивна напруженість (наявність невиконаних вимог), фіксація стійких переживань тривоги та агресії, поява невротичних реакцій (Леонтьева \& Качина, 2006).

Тривалий стрес на роботі у менеджерів комерційних організацій проявляється у формуванні таких професійних деформацій, як: авторитарність, демонстративність, підвищена агресивність, професійний догматизм, консерватизм, рольовий експансіонізм, соціальне лицемірство, завищений контроль, неадекватність у сприйнятті людей і ситуацій, яка призводить до втрати конструктивної взаємодії та ін. (Зеep, 2005).

Таким чином, представники професії «менеджер», як і серед інших професій типу «людина-людина», схильні до розвитку синдрому емоційного вигорання, що призводить до психічного дискомфорту, зниження задоволеності професійною діяльністю, появи психосоматичних порушень, що відбивається на якості їх життя.

Мета дослідження полягає у емпіричному дослідженні синдрому емоційного вигорання у менеджерів комерційних організацій. Завдання дослідження: 1) здійснити теоретичний аналіз вивчення проблеми синдрому емоційного вигорання у менеджерів комерційних організацій; 2) емпірично дослідити психологічні особливості емоційного вигорання у менеджерів комерційних організацій; 3) встановити взаємозв'язок між проявами синдрому емоційного вигорання та рівнем тривожності й невротизації досліджуваних.

\section{Методи дослідження}

Емпіричне дослідження проводилось у період з лютого по квітень 2019 року. В дослідженні взяли участь менеджери комерційних організацій і підприємств у м. Кривий Ріг: ПАТ «Арселор Міттал Кривий Ріг», ТОВ «Алькор Л.А.О». Загальна кількість досліджуваних склала 40 осіб різної статі, вік респондентів від 33 до 58 років. У ході дослідження використовувались надійні та валідні методики, що забезпечували достовірність результатів і застосовувався метод рангової кореляції ( $\mathrm{r}$ - Спірмена).

Для визначення психологічних особливостей синдрому емоційного вигорання нами був підібраний такий банк методик: для визначенні ступеню вираженості загального рівня синдрому емоційного вигорання, сформованості окремих його фаз і симптомів була застосована методика «Діагностика рівня емоційного вигорання» В. Бойко. За допомогою методики «Індекс життєвого стилю» (Life Style Index) Плутчека-Келлермана - Конте емпірично було досліджено механізми психологічного захисту, що виникають у менеджерів комерційних організацій 3 синдромом емоційного вигорання. 3 метою мінімізації впливу індивідуальних особливостей особистості на прояви емоційного 
вигорання було використано методику вимірювання рівня тривожності Тейлора (адаптація Т. Нємчинова), для діагностики рівня невротизації - методику Л. Вассермана.

\section{Результати та дискусії}

За допомогою методики «Діагностика рівня емоційного вигорання» В. Бойко, ми дослідили симптоми та фази розвитку емоційного вигорання. Отримані результати свідчать, що у 25\% досліджуваних фаза напруження несформована на відміну від тих респондентів у яких ця фаза знаходиться на стадії формування та домінують симптоми незадоволеності собою, що складає $75 \%$. Це свідчить про те, що менеджери комерційних організацій періодично відчувають себе некомфортно на робочому місці, через відсутність задоволення від своєї професії й посади, від виконання обов'язків. Респондентів, у яких фаза напруження сформована, не виявлено.

Фаза резистенції у 13\% досліджуваних несформована, порівняно з 37\% у яких дана фаза знаходиться на стадії формування. У 50\% обстежених ця фаза сформована. Домінуючі симптоми на цій фазі є: симптом неадекватного вибіркового емоційного реагування та симптом редукції професійних обов'язків, які у більшості респондентів $\epsilon$ сформованими. Це свідчить про те, що менеджери комерційних організацій прагнуть мінімалізувати свої емоції, проявляючи байдужість до інших, неохоче спілкуються із колегами та партнерами, намагаються уникати обов'язків, які потребують надмірного емоційного напруження.

За шкалою виснаження 39\% респондентів знаходяться на стадії несформованості. Загальний тонус нервової системи цієї частини досліджуваних знаходиться в задовільному стані, вони не мають фізичного та вираженого психологічного дискомфорту на робочому місці, працьовиті. У 35\% досліджуваних фаза виснаження на стадії формування на противагу тих, у кого ця фаза сформована - 26\%. В цих респондентів в однаковій мірі виражені симптоми емоційного дефіциту, емоційної відчуженості та деперсоналізації. Менеджери, які відчувають емоційний дефіцит, спілкуючись $з$ оточуючими, вдаються до роздратованості, грубості, образ, капризів, у них переважно поганий настрій, а й тому найчастіше уникають взаємодії з іншими людьми, більш самотні. I, як наслідок, погіршення фізичного самопочуття.

Механізми психологічного захисту у менеджерів 3 синдромом емоційного вигорання ми визначили за опитувальником «Індекс життєвого стилю» (Life Style Index) Плучека-Келлермана - Конте. Нами було встановлено, що респонденти вдаються до різних механізмів психологічного захисту, але в більшій мірі використовують механізм раціоналізації (50\%) та проекції (79\%). Ці механізми належать до категорії дефензивних механізмів психологічного захисту, при яких особистість стикаючись 3 труднощами сприймає травмуючу інформацію, але інтерпретує іiі викривленим змістом своїх думок, почуттів, діями та вчинками, хоча на перший погляд вони здаються правдоподібними, тим самим намагаючись не втратити свою самоповагу.

Використання раціоналізації як механізму психологічного захисту свідчить про те, що менеджери, знаходячись в стані психологічного конфлікту, шукають виправдовування за свої дії та вчинки, які суспільство не схвалює. Респонденти намагаються довести, що їх поведінка є раціональною і виправданою, а тому соціально схваленою, вона допомагає долати надмірні емоційні хвилювання та конфліктні ситуації. 
Високий рівень використання механізму проекції свідчить про схильність обстежуваних приписувати власні негативні почуття, переживання, наміри, бажання іншим людям, перекладати на них відповідальність, тим самим усуваючи загрозу образу власного «Я».

За допомогою методики вимірювання рівня тривожності Тейлора (адаптація Т. Нємчинова) ми визначили рівень тривожності у менеджерів комерційних організацій. Отримані результати представлені на рис. 1.

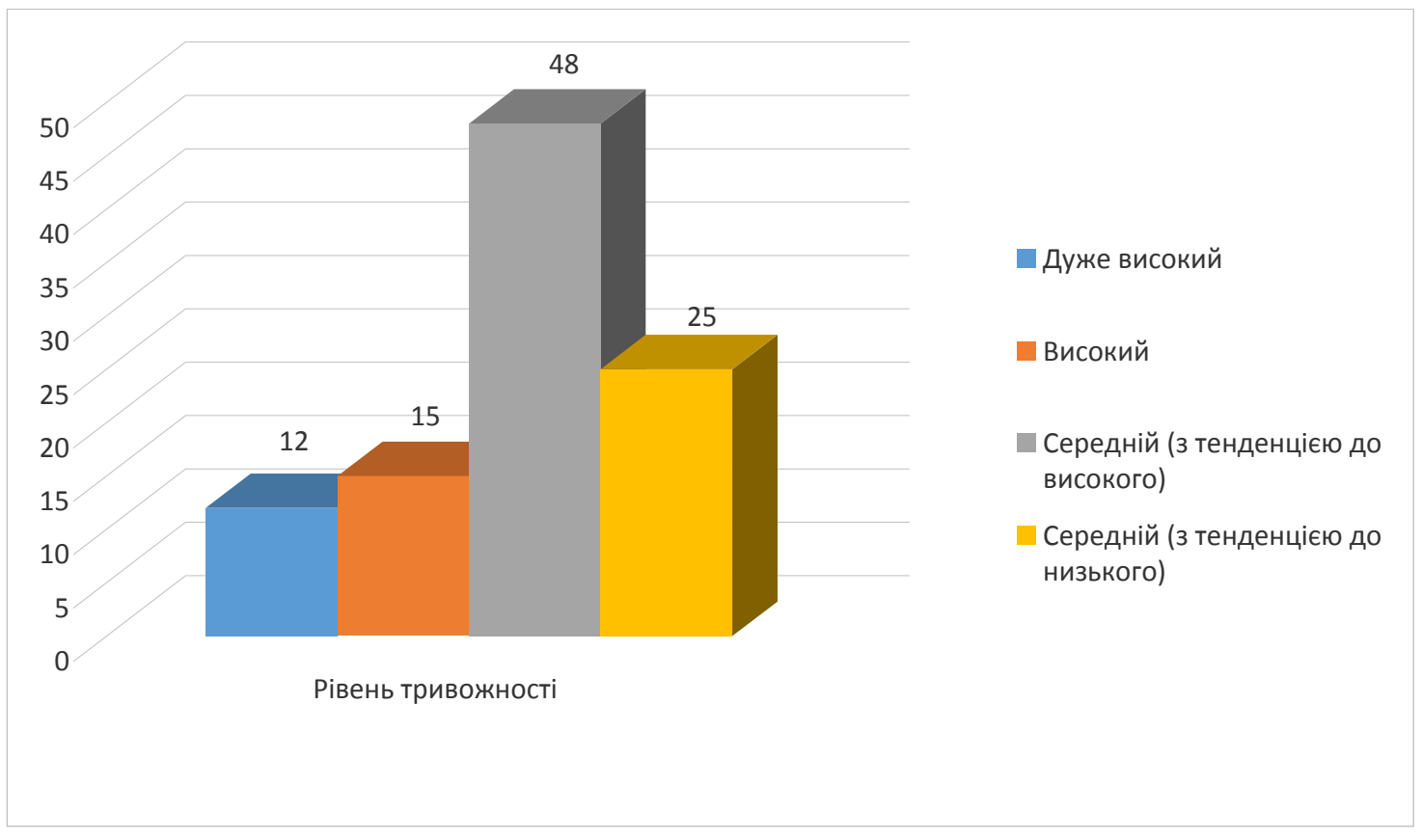

Рис. 1. Рівні прояву тривожності у менеджерів комерційних організацій (\%)

3 рис. 1 видно, що усі досліджувані виявляють той чи інший ступінь прояву тривожності. Найбільшу кількість становлять працівники з середнім (з тенденцією до високого) рівнем тривожності - 48\% від загальної кількості досліджуваних. Це означає, що у таких працівників спостерігаються час від часу такі прояви тривожності, як: знижений настрій, коливання емоційного стану, хвилювання, занепокоєння, швидка стомлюваність, слабкість, невизначеність та безпорадність, зниження концентрації уваги, уповільнення процесів мислення, швидкості реакцій, працездатності. Це відбивається на їх діяльності, зокрема на якості виконання професійних обов'язків, стосунках з колегами та клієнтами.

Середній рівень (з тенденцією до низького) мають 25\% респондентів. Ця категорія працівників так само схильна до прояву вищезазначених симптомів, але в меншому ступені. Менеджери більш впевнені в собі, врівноважені, виявляють змогу знижувати нервове напруження, долати стреси, швидко і легко адаптуватися до нових умов діяльності.

Високий рівень тривожності виявлений у 15\% респондентів. Такі працівники характеризуються схильністю не тільки до психологічних проявів тривоги, але й до фізіологічних, які проявляються достатньо часто і виражаються в тремтінні, прискореному серцебитті, м'язовому напруженні. 
Дуже високий рівень тривожності мають 12\% респондентів. Такі працівники схильні перебільшувати ситуацію загрози, що впливає на їх самооцінку та життєдіяльність. У них спостерігається інтенсивність емоційних процесів, гострота реакцій на свої невдачі, найчастіше працюють у стресових ситуаціях або в умовах дефіциту часу, відведеного на розв'язання завдання. Така тривожність дезорганізує їх поведінку та діяльність. Респондентів з низьким рівнем тривожності не виявлено.

Особливості прояву невротизації особистості було досліджено за допомогою стандартизованої методики для визначення рівня невротизації Л. Вассермана. Результати дослідження подано на рис. 2.

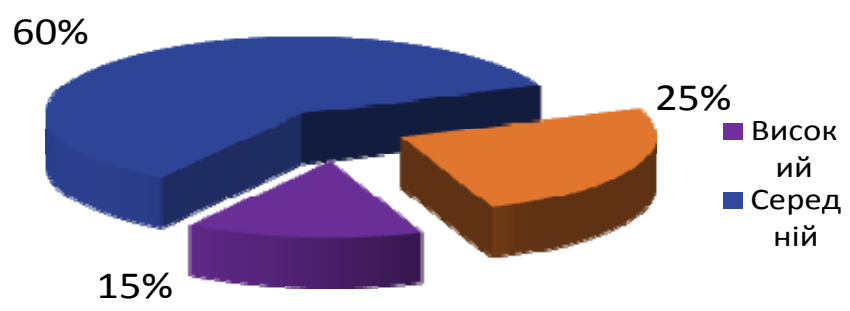

\section{Рис. 2. Рівні прояву невротизації у менеджерів комерційних організацій}

3 рис. 2 видно, що $60 \%$ респондентів мають середній рівень невротизації. У таких менеджерів спостерігається прояви емоційної реактивності, яка відображається на ставленні особистості до навколишньої дійсності та до себе самої. Менеджери схильні до негативних переживань, пов'язаних з незадоволенням власних потреб і бажань, у них спостерігається швидка втомлюваність, яка впливає на продуктивність та ефективність праці, зниження настрою. У 15\% досліджуваних рівень невротизації високий. Це свідчить про високу емоційну збудливість, в результаті якої з'являються негативні переживання, як тривожність, напруженість, занепокоєння, розгубленість, дратівливість. Незадоволеність бажань призводить до безініціативності, появою труднощів у спілкуванні, небажання приймати рішення й відповідати за них, зосередження особистості на соматичних відчуттях і своїх недоліках. Лише низький рівень невротизації виявлений у 25\% досліджуваних. Такі менеджери емоційно врівноважені, спокійні, мають почуття власної гідності, ініціативні та легкі в спілкуванні.

Для характеристики результатів, отриманих в ході емпіричного дослідження на основі застосування обраних методик, була проведена статистична перевірка кореляційного аналізу r-Спірмена. Нами встановлено статистично значущий позитивний взаємозв'язок між тривожністю та проявами синдрому емоційного вигорання: «загнаність в клітку» ( $\mathrm{r}=0,433$ при $\mathrm{p} \leq 0,01)$, розширення сфери економії емоцій $(\mathrm{r}=0,539$ при $\mathrm{p} \leq 0,01)$ - у фазі «резистенції»; деперсоналізації ( $\mathrm{r}=0,526$ при $\mathrm{p} \leq 0,01)$, психосоматичні та 
вегетативні порушення $(\mathrm{r}=0,509$ при $\mathrm{p} \leq 0,01)-$ у фазі «виснаження». Був встановлений взаємозв'язок між невротизацією та такими симптомами вигорання, як переживання психотравмуючих обставин $(\mathrm{r}=0,555$ при $\mathrm{p} \leq 0,01)$, тривога і депресія $(\mathrm{r}=0,444$ при $\mathrm{p} \leq 0,01)$ - у фазі «напруження», розширення сфери економії емоцій $(\mathrm{r}=0,612$ при $(\mathrm{p} \leq 0,01)-\mathrm{y}$ фазі «резистенції»; деперсоналізація ( $\mathrm{r}=0,718$ при $\mathrm{p} \leq 0,01)$, психосоматичні та вегетативні порушення $(\mathrm{r}=0,659$ при $\mathrm{p} \leq 0,01)-$ у фазі «виснаження».

Отже, результати дослідження свідчать, що емоційне вигорання та рівень тривожності й невротизації особистості знаходяться в прямій залежності. Менеджери, що виявляють такі особливості, схильні до виникнення та розвитку синдрому емоційного вигорання у професійній сфері й, навпаки, спеціалісти, які здатні контролювати i регулювати свої емоції, більш стійкі до стресу, в них сформовані вольові якості та розвинуті професійно важливі риси, які визначають продуктивність діяльності, мають меншу вірогідність емоційного вигорання.

\section{Висновки}

За результатами проведеного дослідження можна зробити такі висновки: синдром емоційного вигорання повністю обмежує можливості людини підтримувати свою працездатність при розв'язанні професійних завдань i адекватно діяти в умовах психотравмуючих ситуацій. Це комплекс тривожно-депресивних переживань, який деформує ставлення людини до себе та до світу. В такому стані особистість втрачає здатність адекватно оцінювати реалії життя.

Фазами формування синдрому емоційного вигорання у менеджерів комерційних організацій є: фаза напруження, фаза резистенції, фаза виснаження. Домінуючими симптомами вигорання у фазі напруження є: незадоволення собою, своєю професією, посадою, конкретними обов'язками; у фазі резистенції - симптом неадекватного вибіркового емоційного реагування та симптом редукції професійних обов'язків; у фазі виснаження - симптоми емоційного дефіциту, емоційної відчуженості та деперсоналізації.

Менеджери комерційних організацій застосовують переважно такі механізми психологічного захисту, як раціоналізація та проекція. Виявляють схильність до приписування власних негативних почуттів, переживань, намірів, бажань іншим людям. Шукають переконливі докази, виправдування для пояснення своїх дій і бажань, які $\epsilon$ недостатньо схвалюваними.

Майже половина респондентів із загальної вибірки досліджуваних мають середній рівень тривожності та невротизації. Відчувають постійно зниження настрою, хвилювання, занепокоєння, швидку втомлюваність, слабкість, незадоволення своїх потреб і бажань, невизначеність у майбутньому. Встановлено статистично значущий позитивний взаємозв'язок між проявами синдрому емоційного вигорання та рівнем тривожності й невротизації у менеджерів комерційних організацій.

Перспективи подальших досліджень вбачаємо у розробці психокорекційної програми щодо запобігання синдрому емоційного вигорання у менеджерів комерційних організацій. 


\section{Література}

1. Бойко, В. (2003). Синдром эмоционального «выгорания» в профессиональном общении. Санкт-Петербург.

2. Величковская, С.Б. (2005). Зависимость возникновения и развития стресса от факторов профессиональной деятельности педагогов. (Дисс. канд. психол. наук). Москва.

3. Водопьянова, Н., \& Старченкова, Е. (2008). Синдром выгорания: диагностика и профилактика. Санкт-Петербург.

4. Грабе, М. (2008). Синдром выгорания - болезнь нашего времени. Почему люди выгорают и что можно против этого предпринять. Санкт-Петербург: Речь.

5. Зеер, Э.Ф. (2005). Психология профессий. Москва: Академический проект.

6. Карамушка, Л.М., \& Зайчикова, Т.В. (2006). Проблема синдрому «професійного вигорання» в педагогічній діяльності в зарубіжній та вітчизняній психології. Актуальні проблеми психології: зб. наук. пращьь Інституту психології ім. Г.С. Костюка АПН Украӥни, 1, 210-217.

7. Кочюнас, Р. (1990). Основы психологического консультирования. Москва: Академический проект.

8. Леонтьева, А.Б., \& Качина, А.А. (2006). Особенности синдрома профессионального стресса у менеджеров разного должностного статуса. Психология психических состояний, 6, 250-273.

9. Никифоров, Г.С. (2002). Психология здоровья. Санкт-Петербург: Речь.

10. Орел, В. (2001). Феномен «выгорания» в зарубежной психологии: эмпирические исследования. Психологический журнал, 22 (1), 90-101.

11. Селье, Г. (1982). Стресс без дистресса. Москва: Прогресс.

12. Hobfoll, S. (2001). "The Influence of culture, community, and the nested-self in the stress process: Advancing conservation of resources theory». Applied Psychology, 50 (2), 337-421. https://doi.org/10.1111/1464-0597.00062

13. Jurado, M., Pérez-Fuentes C., Linares, G., Márquez, S., \&. Martínez, M. (2018). «Burnout risk and protection factors in certified nursing aides». International Journal of Environmental Research and Public Health, 15 (6), 245. https://doi.org/10.3390/ijerph15061116

14. Jurado, M., \& Pérez-Fuentes, C. (2019). Burnout, perceived efficacy, and job satisfaction: Perception of the educational context in high school teachers. BioMed Research International, 3, 1-10. https://doi.org/10.1155/2019/1021408.

15. Maslach C., Schaufeli W., \& Leiter, M. (2001). Job Burnout. Annual Review of Psychology, $52,397-422$.

16. Mérida-López, S., \& Extremera, N. (2017). Emotional intelligence and teacher burnout: A systematic review. International Journal of Educational Research, 85, 121-130. https://doi.org/10.1016/j.ijer.2017.07.006

17. Ventura, M., Salanova, M., \& Llorens, S. (2015). «Professional self-efficacy as a predictor of burnout and engagement: The role of challenge and hindrance demands». The Journal of Psychology: Interdisciplinary and Applied, $149 \quad$ (3), 277- 302. https://doi.org/10.1080/00223980.2013.876380

\section{References}

1. Bojko, V. (2003). Sindrom jemocional'nogo «vygoranija» v professional'nom obshhenii [Emotional "burnout" syndrome in professional communication]. St. Petersburg: Peter [in Russian].

2. Velychkovskaja, S. B. (2005). Zavysymost' voznyknovenyja y razvytyja stressa ot faktorov professyonal'noj dejatel'nosty pedagogov [Dependence of the occurrence and development 
of stress on the factors of professional activity of teachers]: $\mathrm{PhD}$ dissertation. Moscow [in Russian].

3. Vodop'janova, N. \& Starchenkova, E. (2008). Syndrom vyygoranyja: dyagnostyka y profylaktyka [Burnout Syndrome: diagnosis and prevention]. St. Petersburg: Peter [in Russian].

4. Grabe, M. (2008). Syndrom vyygoranyja - bolezn' nashego vremeny. Pochemu ljudy vyygorajut y chto mozhno protyv эtogo predprynjat' [Burnout syndrome - a disease of our time. Why do people burn out and what can be done against it]. St. Petersburg: Rech [in Russian].

5. Zeer, Je.F. (2005). Psihologija professij [Psychology of professions]. Moscow: Akademicheskij proekt [in Russian].

6. Karamushka, L.M., \& Zajchykova, T.V. (2006). Problema syndromu «profesijnogo vygorannja» $\mathrm{v}$ pedagogichnij dijal'nosti $\mathrm{v}$ zarubizhnij ta vitchyznjanij psyhologii' [The problem of «professional burnout» syndrome in pedagogical activity in foreign and domestic psychology]. Aktual'ni problemy psyhologii': zb. nauk. prac' Instytutu psyhologii' im. G.S. Kostjuka APN Ukrai'ny, 1, 210-217 [in Ukrainian].

7. Kochjunas, R. (1990). Osnovy psihologicheskogo konsul'tirovanija [Basics of psychological counseling]. Moscow: Akademicheskij proekt [in Russian].

8. Leont'eva, A.B., \& Kachina, A.A. (2006). Osobennosti sindroma professional'nogo stressa u menedzherov raznogo dolzhnostnogo statusa [Features of occupational stress syndrome among managers of different job status]. Psihologija psihicheskih sostojanij, 6, 250-273 [in Russian].

9. Nikiforov, G.S. (2002). Psihologija zdorov'ja [Health psychology]. Uchebnoe posobie. St. Petersburg: Rech. [in Russian].

10. Orel, V. (2001). Fenomen «vyygoranyja» v zarubezhnoj psyhologyy: эmpyrycheskye yssledovanyja [The phenomenon of «burnout» in foreign psychology: empirical research]. Psyhologycheskyj zhurnal, 22 (1), 90-101 [in Russian].

11. Sel'e, G. (1982). Stress bez distressa [Stress without distress]. Moscow: Progress [in Russian].

12. Hobfoll, S. (2001). "The Influence of culture, community, and the nested-self in the stress process: Advancing conservation of resources theory». Applied Psychology, 50 (2), 337-421. https://doi.org/10.1111/1464-0597.00062

13. Jurado, M. Pérez-Fuentes, Linares, G., Márquez, S., \&. Martínez, M. (2018). «Burnout risk and protection factors in certified nursing aides». International Journal of Environmental Research and Public Health, 15 (6), 245. https://doi.org/10.3390/ijerph15061116.

14. Jurado, M., \& Pérez-Fuentes, C. (2019). Burnout, perceived efficacy, and job satisfaction: Perception of the educational context in high school teachers. BioMed ResearchInternational, 3, 1-10. https://doi.org/10.1155/2019/1021408.

15. Maslach C. Schaufeli W., \& Leiter, M. (2001). Job Burnout. Annual Review of Psychology, $52,397-422$.

16. Mérida-López, S., \& Extremera, N. (2017). Emotional intelligence and teacher burnout: A systematic review. International Journal of Educational Research, 85, 121-130. https://doi.org/10.1016/j.ijer.2017.07.006

17. Ventura, M. Salanova, M., \& Llorens, S. (2015). «Professional self-efficacy as a predictor of burnout and engagement: The role of challenge and hindrance demands», The Journal of Psychology: Interdisciplinary and Applied, 149 (3), 277-302. https://doi.org/10.1080/00223980.2013.876380 


\title{
PSYCHOLOGICAL FEATURES OF EMOTIONAL BURNOUT SYNDROME IN THE MANAGERS OF COMMERCIAL ORGANIZATIONS Olha Sydorenko
}

PhD in Psychology, Associate Professor, Associate Professor of the Department of General and Social Psychology and Psychotherapy

National Pedagogical Dragomanov University

9, Pyrohov Str., Kyiv, Ukraine, 01601

OlgaBorisoUA@gmail.com, https://orcid.org/0000-0003-0925-4966

\author{
Elha Yanovska \\ Graduate student, Specialty «Psychology», Psychology Faculty \\ hemmmy20@gmail.com, https://orcid.org/0000-0002-8676-9544 \\ National Pedagogical Dragomanov University \\ 9, Pyrohov Str., Kyiv, Ukraine, 01601
}

\begin{abstract}
The theoretical analysis of scientific approaches to the interpretation of the concept «Emotional burnout» is presented in the article, its symptoms are covered. Emotional burnout is a state of emotional, mental, physical exhaustion that develops as a result of chronic stress caused by one's own work and combines emotional devastation, depersonalization and reduction of one's personal achievements. The causes and peculiarities of emotional burnout are revealed. The main groups of factors that cause the emergence of emotional burnout syndrome are identified: personal, role, organizational. Phases of formation of emotional burnout syndrome in managers of commercial organizations are revealed: phase of tension, phase of resistance, phase of exhaustion. The dominant symptoms of burnout in the phase of tension are: dissatisfaction with oneself, one's profession, position, specific responsibilities; in the phase of resistance, a symptom of inadequate selective emotional response and a symptom of reduction of professional responsibilities; in the exhaustion phase - symptoms of emotional deficiency, emotional estrangement and depersonalization. The study revealed that managers of commercial organizations mainly use such mechanisms of psychological protection as rationalization and projection. They show a tendency to attribute their own negative feelings, intentions, wishes to other people. They are looking for convincing evidence and justification for explaining their actions and wishes that are not well encouraged. These are the attempts of the researchers to prove that their behavior is rational and justified, and therefore socially approved, it helps to resolve conflict situations or overcome difficulties on the way to the goal, avoiding excessive emotional disturbance. Almost half of the respondents have an average level of anxiety and neurotization. They feel a constant decrease in mood, excitement, worry, rapid fatigue, weakness, dissatisfaction with their needs and wishes, uncertainty in the future.

A statistically significant positive correlation was found out between the manifestations of the emotional burnout syndrome and the level of anxiety and neurotisation in managers of commercial organizations. It was stated that the development of an appropriate psychocorrective program will help to prevent the emotional burnout syndrome in the managers of commercial organizations.
\end{abstract}

Keywords: emotional burnout, anxiety, neurotization, stress, managers of commercial organizations, professional deformation.

Подано 29.01.2020

Рекомендовано до друку 03.02.2020 